Sains Malaysiana 49(8)(2020): 1905-1913

http://dx.doi.org/10.17576/jsm-2020-4908-12

\title{
Molecular Docking Study of the Interactions between Plasmodium falciparum Lactate Dehydrogenase and 4-aminoquinoline Hybrids
}

(Kajian Dok Molekul Mengenai Interaksi antara Hibrid 4-aminokuinolina dan Plasmodium falciparum Laktat Dehidrogenase)

\author{
NUR HANIS ZAKARIA, LAM KOK WAI \& NURUL IZZATY HASSAN*
}

\begin{abstract}
Malaria is a potentially deadly disease with many anti-malarial drugs have been rendered ineffective due to Plasmodium falciparum resistance concern. Plasmodium falciparum lactate dehydrogenase (PfLDH) enzyme is a crucial malaria parasite enzyme involved in the glycolytic pathway, thus, has been considered as a potential molecular target. Initially, molecular docking was performed using AutoDock Vina, Molegro Virtual Docker, and CDOCKER software to investigate the molecular interactions of 4-aminoquinoline antimalarial hybrids compounds with PfLDH enzyme. All ten 4-aminoquinoline hybrids derivatives docked to the PfLDH binding site. The results showed that these compounds exhibited either comparable or higher binding affinity than the reference drug chloroquine, amodiaquine, and hydroxychloroquine. Visually, some of the compounds possessed functional binding interactions, possibly due to their similar structural conformation and binding interactions of chloroquine in the binding site. Apart from that, the docking results also suggest that these compounds potentially promote additional hydrogen-bonding interactions with the residues in the binding site. Interestingly, the compounds also predicted to interact with essential PHE52, VAL26, ILE54, ILE119, and ALA98 residues, which are required to act as a competitive inhibitor for this glycolytic enzyme.
\end{abstract}

Keywords: 4-aminoquinoline; malaria; molecular docking; Plasmodium falciparum lactate dehydrogenase (PfLDH) enzyme

ABSTRAK

Malaria merupakan antara penyakit yang boleh menyebabkan kematian dengan peningkatan kerintangan ubat-ubatan anti-malaria sedia ada. Enzim Plasmodium falciparum dehidrogenase (PfLDH) merupakan enzim sasaran yang terlibat dalam laluan glikolitik. Oleh itu, kajian dok molekul telah dijalankan menggunakan perisian AutoDock Vina, Molegro Virtual Docker dan CDOCKER untuk mengkaji interaksi molekul antara 4-aminokuinolina antimalaria hibrid terhadap PfLDH enzim. Kesemua sepuluh sebatian hibrid dilihat sesuai untuk didok menggunakan kedua-dua perisian dan menunjukkan pengikatan keafinan yang baik dan setanding dengan pengikatan keafinan sebatian klorokuina, amodiakuina dan hidrosiklorokuina. Pengikatan keafinan yang baik dan setanding klorokuina disebabkan persamaan struktur bentuk dengan klorokuina pada tapak pengikat selain kemampuan menambah ikatan hidrogen. Sebatian juga berinteraksi dengan asid amino yang penting sebagai perencat bersaing untuk enzim glikolitik. Semua asid amino yang penting termasuklah PHE52, VAL26, ILE54, ILE119 dan ALA98.

Kata kunci: Dok molekul; enzim Plasmodium falciparum dehidrogenase (PfLDH); malaria; 4-aminokuinolina

\section{INTRODUCTION}

Malaria, a widespread tropical disease caused by the protozoan parasite of the genus Plasmodium, was responsible for an estimated 228 million cases in 2018, with the vast majority occurring in WHO African region (93\%) followed by WHO South-East Asia Region (3.4\%) mainly in children under five years of age. Plasmodium falciparum is the most prevalent malaria parasite in sub-Saharan Africa, accounting for $99.7 \%$ of estimated malaria cases in 2018. Outside of Africa, Plasmodium vivax is the predominant parasite representing $53 \%$ of malaria cases (WHO 2019). For decades, quinoline based antimalarials such as chloroquine used for the treatment of malaria due to its low cost, safety, and efficacy. However, due to its extensive global use, chloroquine-resistant Plasmodium falciparum and Plasmodium vivax have now been reported in every endemic malaria country, thus complicates the treatment. In response to this, a vast number of modified chloroquine molecules designed to overcome resistance in malaria.

An idea for chloroquine mechanism of action comes from the observation that it is active only against 
the erythrocytic stages of parasites. The previous study showed that chloroquine could potentially interfere with the parasite feeding process (Waingeh et al. 2013). Targeting enzymes responsible through glycolytic pathways is thought to be an essential drug target for malaria treatment. For example, lactate dehydrogenase (LDHs) is an essential enzyme for parasite survival as it catalyzes the reduction of the keto group in pyruvate to hydroxyl with the concomitant oxidation of NADH to $\mathrm{NAD}^{+}$. Furthermore, protozoal LDHs have structural and kinetic differences to their mammalian equivalents, which will be beneficial for the development of drug selectivity (Chaikuad et al. 2005).

Chloroquine binds in or near to the cofactor binding site of $P f \mathrm{LDH}$, suggesting the compound act as an inhibitor for this enzyme (Read et al. 1999; Waingeh et al. 2013). The computer-aided drug design approach, molecular docking was utilized in this study to investigate the binding interactions of designed antimalarials hybrids compounds with the residues in the active site of PfLDH. Besides, this study also aimed to search for the best orientation of the ligand-enzyme complex with the lowest binding energy. Thus, the basis of the distinct activity profile of 4-aminoquinoline hybrid proposed towards the PfLDH enzyme realized. In general, the molecular docking process allows for better understanding of newly designed molecules to their target protein molecules besides providing an economical identification approach for potential compounds (Shadrack et al. 2016).

\section{MATERIALS AND METHODS}

\section{MOLECULAR DOCKING}

Ten derivatives of 4-aminoquinoline hybrids prepared in this study (Figure 1). The ligand's 3D structures were drawn using ChemDraw Professional 15.0 and minimized to stabilize their structural energy. The protein crystal structure of the $P$. falciparum lactate dehydrogenase $(P f \mathrm{LDH})$ enzyme with cofactor retrieved from the Protein data bank (PDB ID:1CET, resolution: $2.05 \AA$ ). The protein crystal structure was pre-treated before the docking process. The respective ligands, non-protein molecules, and water molecules were removed and employed as receptors for the docking analysis. Discovery Studio 2016 (Accelrys Inc. San Diego, CA, USA) used for the protein and ligand preparation. As for the ligand structure preparation, the 2D structure of antimalarial hybrids drawn in the ChemDraw program before further energy minimization using the same software. Subsequently, the 2D ligand structures converted to PDB files. The PDB files prepared for docking in AutoDock Vina, Molegro Virtual Docker, and CDOCKER software.

\section{AUTODOCK VINA}

Each of the protein crystal structure and ligands were loaded and converted to pdbqt format, respectively.
Hydrogen and partial charges added, and the target site assigned along with the dimension. Ligands were also loaded and converted into pdbqt format. The best free energy of binding values obtained by using the command prompt to run the docking. The docking visualization of ligands and PfLDH visualized in Discovery Studio 2.5.5 (Trott \& Olson 2010).

\section{MOLEGRO VIRTUAL DOCKER(MVD)}

Molegro virtual docker uses cavity detection algorithm to detect potential binding site which has an active region to bind the drug. Protein crystal structure and ligands imported into the worksheet. Under the protein and ligand preparation tab, all features were assigned to 'Always' to ensure that MVD will do all preparation. Prediction of the binding site on the protein was made by selecting 'preparation' and 'detect cavities' parameter. Reference ligand and docking template of reference drugs set to get specific binding of the newly designed drugs. Docking made by choosing the smallest grid resolution with ten poses generation. The best energy of binding values obtained. The docking visualization of ligands and $P f \mathrm{LDH}$ visualized in the workspace and Discovery Studio 2.5.5. (Thomsen \& Christensen 2006).

\section{CDOCKER}

CDOCKER algorithm is a grid-based molecular docking method. All ten newly designed compounds were submitted to CHARMm (Chemistry at HARvard Macromolecular Mechanics) force field for structure refinement. All ligands were energy minimized using the CHARMm force field to make stable conformation of protein with an energy gradient of $0.01 \mathrm{kcal} / \mathrm{mol} / \AA$. For each final pose, the CHARMm energy obtained as a result of interaction energy plus ligand strain calculated. The docked conformation with the lowest interaction energy was selected. The docking visualization of ligands and $P f \mathrm{LDH}$ visualized in Discovery Studio 2.5.5. (Wu et al. 2003).

\section{DRUG LIKENESS ASSESSMENT}

Drug-likeness of ten derivatives of 4-aminoquinoline hybrids evaluated further using Lipinski's rule of five. It is an empirical rule of thumb to evaluate physicochemical properties and refine drug ability for small molecules. ChemDraw Professional 15.0 software and Sanjeevini web server were utilised to calculate and predict the value of LogP, hydrogen bond donor and acceptor as well as the molecular weight (Jayaram et al. 2012). These hybrids should compose of no more than five hydrogen bond donors and ten hydrogen bond acceptors. The increasing number of hydrogen bonds may reduce partitioning from the aqueous phase into the lipid bilayer membrane for permeation by passive diffusion. Furthermore, the compound's molecular mass must be less than 500 Daltons as increasing molecular weight reduces the compound 
concentration at the surface of the intestinal epithelium, hence lessens the absorption. An octanol-water partition coefficient Log P must not be greater than five to prevent poor absorption or permeation (Kalita et al. 2019).
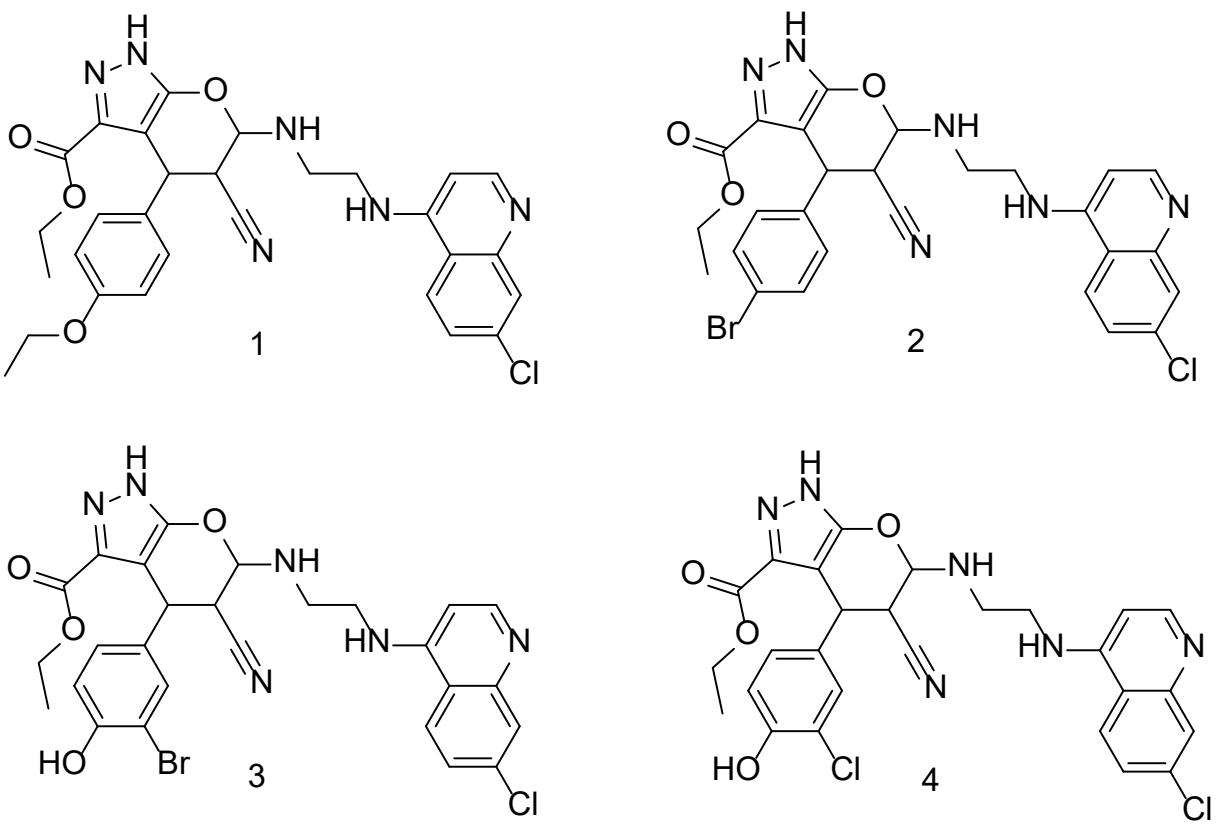<smiles>CCOC(=O)c1n[nH]c2c1C(c1cccs1)C(C#N)C(NCCNc1ccnc3cc(Cl)ccc13)O2</smiles><smiles>CCCCCCCC1c2c(C(=O)OCC)n[nH]c2OC(NCCNc2ccnc3cc(Cl)ccc23)C1C#N</smiles><smiles>CCOC(=O)c1n[nH]c2c1C(C1CCN(C)CC1)C(C#N)C(NCCNc1ccnc3cc(Cl)ccc13)O2</smiles><smiles>CCOC(=O)c1n[nH]c2c1C(C1CCSCC1)C(C#N)C(NCCNc1ccnc3cc(Cl)ccc13)O2</smiles><smiles>CCOC(=O)c1n[nH]c2c1C(CC)C(C#N)C(NCCNc1ccnc3cc(Cl)ccc13)O2</smiles><smiles>CCOC(=O)c1n[nH]c2c1C(c1ccccc1)C(C(=O)OCC)C(NCCNc1ccnc3cc(Cl)ccc13)O2</smiles>

FIGURE 1. Ten derivatives of 4-aminoquinoline hybrid compounds

(1-10) utilized in the in silico study 


\section{RESULTS AND DISCUSSION}

Molecular docking is a virtual tool intended to find the best binding orientation of newly designed molecules to their target protein molecules. It is useful to predict the binding affinity as well as the biological efficacy of small molecules (Kitchen et al. 2004). Thus, to gain insights into the critical structural needed and the basis of the distinct activity profile of ten newly proposed and designed 4-aminoquinoline hybrids toward the PfLDH enzyme, a molecular docking study was conducted. For the selection of protein target, 1CET protein (resolution of $2.05 \AA$ ) was used for it provides crystal structure of complex formed between chloroquine and $p f \mathrm{LDH}$ enzyme. The structure of this enzyme-inhibitor complex provides a template for which the 4-aminoquinoline hybrids to be docked (Read et al. 1999). In the beginning, the chloroquine crystal ligand was docked to the protein crystal structure of 1CET protein to verify the accuracy and reliability of software to be used in this study (Chaikuad et al. 2005). Figure 2 shows the superposition of chloroquine crystal structure as observed in the crystallographic structure of PfLDH, and the best chloroquine docking conformation obtained in the same binding site as predicted by AutoDock Vina, Molegro Virtual Docker, and CDOCKER, respectively. All software was capable of accurately predicting the chloroquine binding orientation, as shown in the ligandprotein complex crystal structure. The result suggests that all three software were suitable to be used in subsequent docking study. The RMSD generated out from the superposition of the crystal ligand and docked ligand were of $1.36 \AA$ (AutoDock Vina), $1.67 \AA$ (CDOCKER), and 0.72 $\AA$ (Molegro Virtual Docker), respectively.

The docking results showed that all ten newly designed 4-aminoquinoline hybrid compounds exhibited higher binding affinity as compared to chloroquine, amodiaquine, and hydroxychloroquine. Table 1 summarizes the molecular docking results based on the most favourable conformation and highest binding affinity of ten 4-aminoquinoline hybrids. Binding energy is the primary parameter that is generated that guides us on the strength and affinity between ligand and receptor. 4-Aminoquinoline with favourable binding energy proposed to be bonded stronger. The result predicted indicated that the dock scores of all ten 4-aminoquinoline hybrids were consistent in terms of their high binding affinity. Apart from that, all the hybrids displayed higher binding affinity than chloroquine, amodiaquine, and hydroxychloroquine. This study may, therefore, serve as an essential tool for accessing the antimalarial potential of newly design 4-aminoquinoline hybrid as a potential inhibitor for the PfLDH enzyme.

As illustrated in Figure 3, compound 8 exhibited the highest binding affinity of $-7.0 \mathrm{kcal} / \mathrm{mol}$ compared to chloroquine $(-5.9 \mathrm{kcal} / \mathrm{mol})$, amodiaquine $(-5.6 \mathrm{kcal} /$ $\mathrm{mol})$ and hydroxychloroquine $(-5.9 \mathrm{kcal} / \mathrm{mol})$ using
Autodock Vina. Using MVD, compound 8 exhibited Moldock score with a binding energy of $-74.66 \mathrm{kcal} /$ mol while the reference established drugs chloroquine, amodiaquine and hydroxychloroquine with $-61.71 \mathrm{kcal} /$ $\mathrm{mol},-66.31 \mathrm{kcal} / \mathrm{mol}$ and $-56.68 \mathrm{kcal} / \mathrm{mol}$, respectively. On the other hand, CDOCKER showed not many differences in term of binding energy for all ten newly designed 4-aminoquinoline hybrid when compared with the reference established drugs used. Chloroquine, amodiaquine and hydroxychloroquine exhibited -30.81 , -32.27 and $-32.35 \mathrm{kcal} / \mathrm{mol}$, respectively, while compound 8 with $-32.82 \mathrm{kcal} / \mathrm{mol}$.

The designed hybrids, compound $\mathbf{8}$, was selected for further visualization and analysis due to its favourable binding energy profile. The binding mode of compound $\mathbf{8}$ in $2 \mathrm{D}$ in the $3 \mathrm{D}$ poses of bound ligand molecules revealed the best molecular orientation relative to the structure of the receptor, as shown in Figure 3. Table 2 indicates various interactions involved between the protein and compound 8 bindings, especially polar hydrogen bonding interaction. For example, residue ASN83 has established hydrogen bonding interaction with the amines functional group in compound $\mathbf{8}$, which could be responsible for the higher binding affinity. Molecular interaction revealed well-defined binding between binding site residue of receptor studied and newly designed 4-aminoquinoline hybrids. Such interactions brought about the excellent quality of the complex formed between the receptor and the ligand molecule. Analysis of docking interactions then further supports the importance of 4-aminoquinoline moiety in protein-ligand interaction (O’Neill et al. 2006). Hybridization of pyranopyrazole moiety with different substituent then further lead toward the formation of the compound with different conformation suitable for binding. Pyranopyrazole moiety increased the strength of interaction by forming an additional hydrogen bond. This bond then facilitated to afford even stronger interaction of the ligand with the receptor studied.

Amino acids responsible for the binding of chloroquine in the PfLDH binding site are PHE 52, VAL26, ALA98, ILE54, GLU122, and ILE119. Amino acid residue forms a binding groove near the surface of the enzyme. Some of these amino acids, such as ALA98, ILE54, and ILE119, are the same responsible for NADH binding in its binding site (Read et al. 1999). 4-Aminoquinoline hybrids also make specific interactions in the PfLDH binding site. It is noteworthy that the binding interaction formed involving those important amino acids responsible in the chloroquine interaction. Those amino acids include PHE52, VAL26, ILE54, ILE119, PHE 100, ASN83, and ALA98, thus suggesting the potential activity of newly design hybrids (Figure 4).

\section{DRUG LIKENESS ASSESSMENT}

Drug likeness assessment of ten newly designed 
4-aminoquinoline hybrid evaluated using Lipinski's rule of five. This evaluation is beneficial to predict 4-aminoquinoline hybrid drug likeliness characteristics before the compound designed is synthesized (Kalita et al. 2019; Lipinski et al. 1997). The result depicted in Table 3 shows that all designed molecules possess acceptable drug-like properties. Five newly designed 4-aminoquinoline hybrid appeared to adhere to all the rules with only one violation while the remaining derivatives adhered entirely to the rules with two violations. The molecular weight of all the compounds exceeded 500 $\mathrm{g} / \mathrm{mol}$, while the $\log \mathrm{P}$ value of 5 of the compounds is higher than five. Poor oral absorption of a drug molecule observed if the drug molecule violates more than one of five rules. Values of $\log \mathrm{P}$ and molecular weight indicate good membrane permeability and oral bioavailability of compounds. Further modification on their structure would be necessary to refine their ability as a drug from Lipinski's rule evaluation. Ultimately, it can be suggested that the newly designed 4-aminoquinoline hybrid mainly compound 8 poses acceptable drug-likeliness behaviour favourable for membrane permeability with desired drugreceptor interaction.

TABLE 1 . Binding affinity $(\mathrm{kcal} / \mathrm{mol})$ of the favourable conformation based on AutoDock Vina

\begin{tabular}{|c|c|c|c|}
\hline \multirow{2}{*}{ Compounds } & \multicolumn{3}{|c|}{ Best binding affinity } \\
\hline & Vina(kcal/mol) & $\begin{array}{l}\text { CDOCKER } \\
(\mathrm{kcal} / \mathrm{mol})\end{array}$ & $\begin{array}{c}\text { Molegro } \\
\text { Virtual Docker } \\
(\mathrm{kcal} / \mathrm{mol})\end{array}$ \\
\hline 1 & -6.8 & -34.8243 & -64.5686 \\
\hline 2 & -7.1 & -34.917 & -79.3903 \\
\hline 3 & -7.0 & -38.4815 & -75.6134 \\
\hline 4 & -6.9 & -33.4367 & -90.9865 \\
\hline 5 & -6.9 & -33.5367 & -88.9353 \\
\hline 6 & -6.4 & -32.0062 & -83.6099 \\
\hline 7 & -6.3 & -30.5239 & -67.1933 \\
\hline 8 & -7.0 & -32.8165 & -74.6616 \\
\hline 9 & -6.8 & -32.4649 & -69.0346 \\
\hline 10 & -6.4 & -35.8242 & -58.9628 \\
\hline chloroquine & -5.9 & -30.8754 & -61.7052 \\
\hline amodiaquine & -5.6 & -32.2669 & -66.3134 \\
\hline hydroxychloroquine & -5.9 & -32.3515 & -56.6754 \\
\hline
\end{tabular}



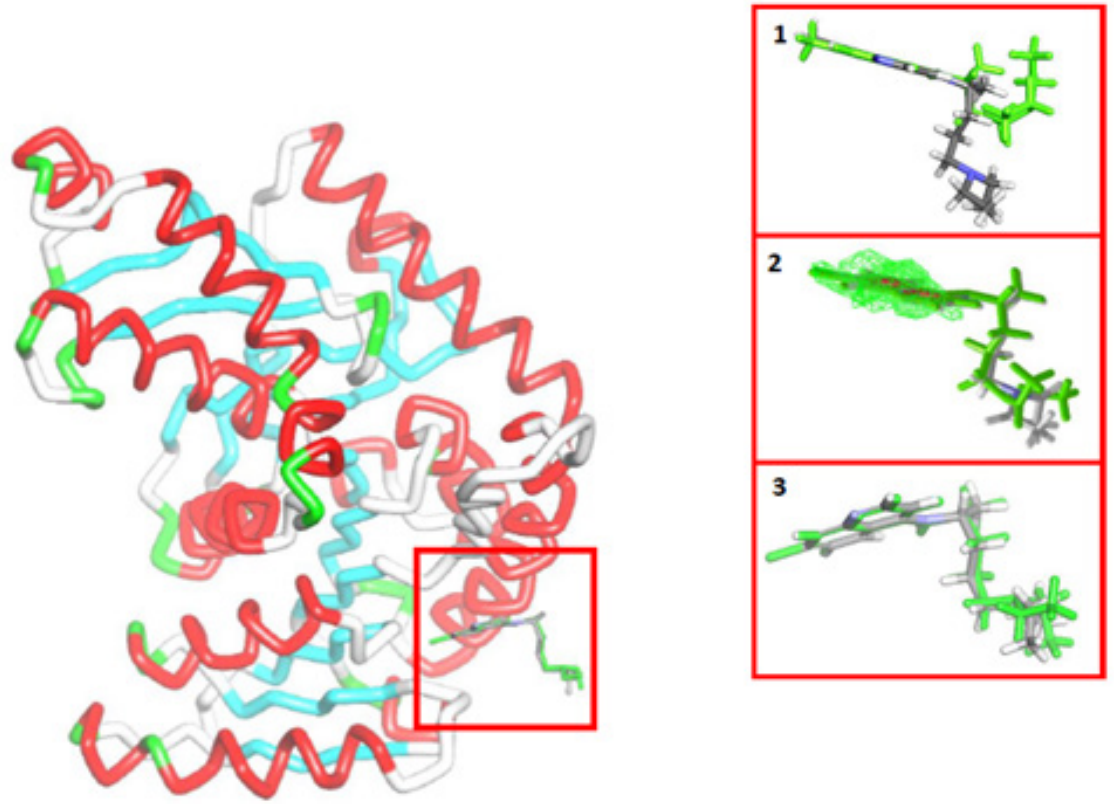

FIGURE 2. Superposition of the chloroquine crystal structure as observed in the crystallographic structure of the PfLDH enzyme and the best docking conformation obtained for chloroquine crystal structure(green) docked inside the same active site using AutoDock Vina(1), Molegro Virtual Docker(2) and CDOCKER(3)

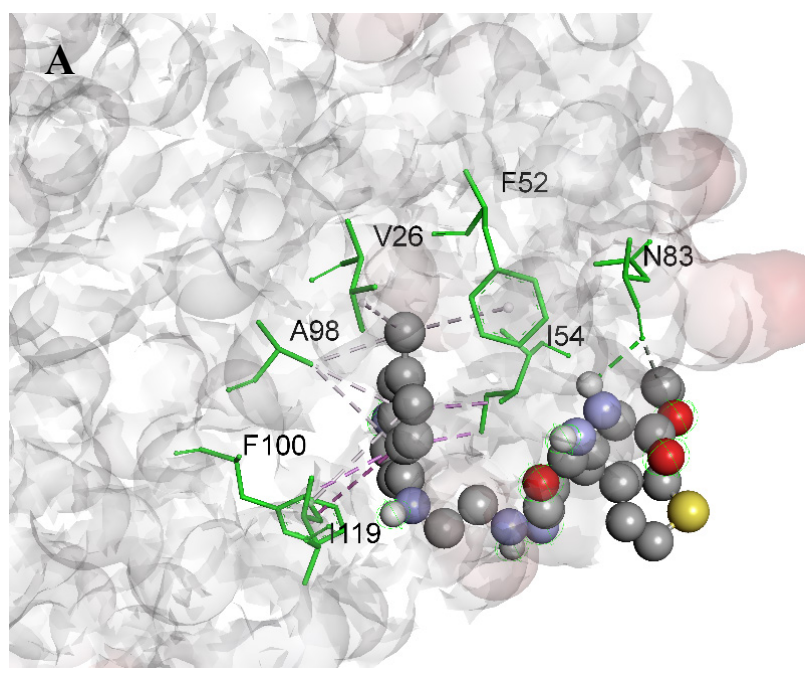

B
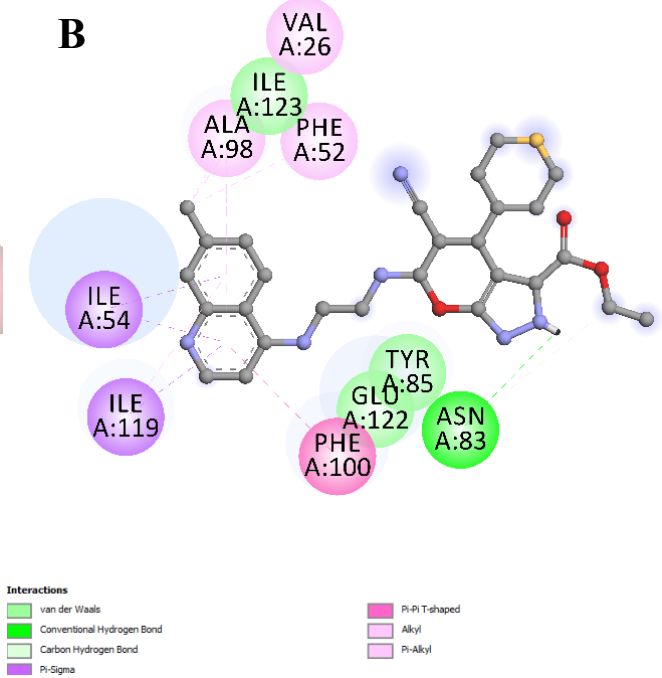

FIGURE 3. The residue of the binding site of $P$. falciparum lactate dehydrogenase ( $P f \mathrm{LDH}$ ) enzyme interacting with compound 8 using Autodock Vina 

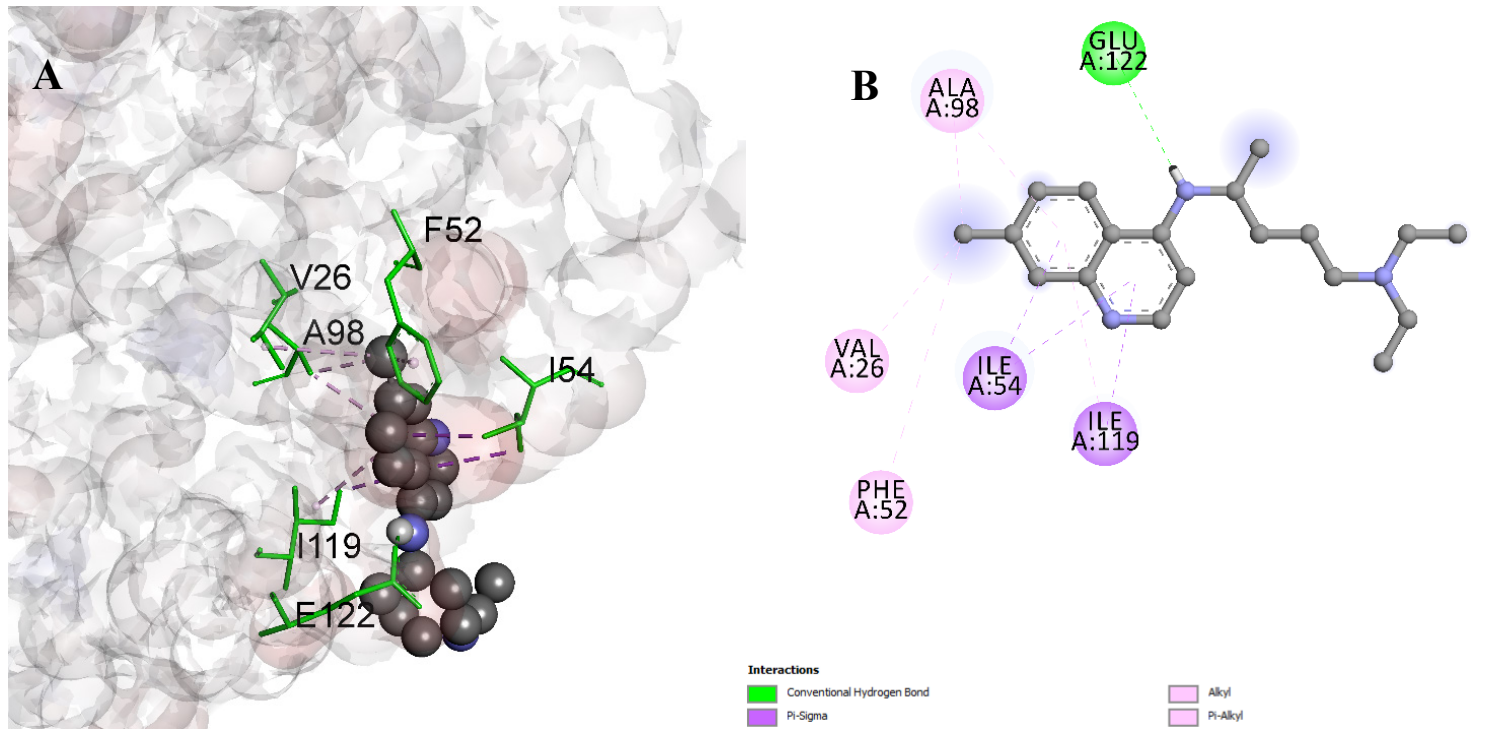

FIGURE 4. The residue of the binding site of $P$. falciparum lactate dehydrogenase $(P f \mathrm{LDH})$ enzyme interacting with chloroquine

TABLE 2. Various interactions involved between receptor and compound $\mathbf{8}$

\begin{tabular}{|c|c|c|c|c|}
\hline \multirow{2}{*}{ Interactions } & Docking software & \multirow{2}{*}{ Vina } & \multirow{2}{*}{$\begin{array}{c}\text { Molegro virtual } \\
\text { Docker }\end{array}$} & \multirow{2}{*}{ CDOCKER } \\
\hline & Amino acids & & & \\
\hline \multirow[b]{2}{*}{ H-Bond } & GLU122 & - & - & 1 \\
\hline & ASN83 & / & - & \\
\hline \multirow{4}{*}{ Van der Waals } & PHE100 & - & - & / \\
\hline & GLU122 & / & - & - \\
\hline & ILE123 & I & - & - \\
\hline & TYR85 & l & - & - \\
\hline \multirow{6}{*}{$\begin{array}{l}\text { Alkyl \& } \\
\pi \text {-alkyl }\end{array}$} & 1LE54 & - & / & / \\
\hline & ILE119 & - & / & / \\
\hline & ALA98 & / & / & - \\
\hline & & & & \\
\hline & PHE52 & / & / & - \\
\hline & VAL26 & / & / & - \\
\hline \multirow{3}{*}{$\pi$-sigma } & ALA98 & - & - & / \\
\hline & ILE54 & I & - & - \\
\hline & ILE119 & / & - & - \\
\hline
\end{tabular}


TABLE 3. Evaluation of Lipinski's rule of five for compound 1-10

\begin{tabular}{lcccc}
\hline $\begin{array}{c}\text { Lipinski rule/ } \\
\text { compounds }\end{array}$ & $\begin{array}{c}\text { Log p(lipophilicity) } \\
<5\end{array}$ & $\begin{array}{c}\text { Hydrogen bond } \\
\text { donor }<5\end{array}$ & $\begin{array}{c}\text { Hydrogen bond } \\
\text { acceptor }<10\end{array}$ & $\begin{array}{c}\text { Molecular } \\
\text { weight }<500 \\
\mathrm{~g} / \mathrm{mol}\end{array}$ \\
\hline 1 & 5.14 & 3 & 10 & 558.5 \\
2 & 5.51 & 3 & 8 & 592.5 \\
3 & 5.21 & 4 & 9 & 608.5 \\
4 & 5.10 & 4 & 9 & 565 \\
5 & 4.81 & 3 & 8 & 529.5 \\
6 & 4.11 & 3 & 8 & 520.5 \\
7 & 6.06 & 3 & 8 & 536.5 \\
8 & 3.39 & 4 & 9 & 542.5 \\
9 & 2.59 & 4 & 10 & 539.5 \\
10 & 3.46 & 4 & 10 & 565.5 \\
chloroquine & 4.81 & 1 & 3 & 319.5 \\
amodiaquine & 5.17 & 2 & 4 & 355.5 \\
hydroxychloroquine & 3.78 & 2 & 4 & 335.5 \\
\hline
\end{tabular}

\section{CONCLUSION}

Ten 4-aminoquinoline hybrid compounds docked to the PfLDH putative binding site using AutoDock Vina, Molegro Virtual Docker, and CDOCKER. All of them have shown promising binding affinity in comparison with chloroquine, amodiaquine, and hydroxychloroquine thus could suggest their strong binding interaction to act as a competitor for this critical glycolytic enzyme. Among them, compound $\mathbf{8}$ displayed the potential binding affinity besides having conformation that fit into chloroquine binding site. It exhibited similar interactions with the amino acid residues as per chloroquine with additional hydrogen bond formation. Drug likeliness studies confirmed likely compound $\mathbf{8}$ as a potential drug. Our present work has provided further understanding of the binding mode and interaction of these 4-aminoquinoline hybrids with the PfLDH enzyme, thus become a reasonable basis towards further molecular optimization of 4-aminoquinoline hybrid as a potential antimalarial.

\section{ACKNOWLEDGEMENTS}

We would like to acknowledge the financial support from the Ministry of Education (FRGS/1/2019/STG01/ UKM/02/3).

\section{REFERENCES}

Chaikuad, A., Fairweather, V., Conners, R., Joseph-Horne, Turgut-Balik, R. \& Brady, L. 2005. Structure of lactate dehydrogenase from plasmodium vivax: Complexes with NADH and $\mathrm{APADH}^{+}$. Biochemistry 44: 16221-16228.

Jayaram, B., Tanya, S., Goutam, M., Abhinav, M., Shashank, S. \& Vandana, S. 2012. Sanjeevini: A freely accessible webserver for target-directed lead molecule discovery. $B M C$ Bioinformatics 13(Suppl 7): S7.

Kalita, J., Chetia, D. \& Rudrapal, M. 2019. Molecular docking, drug-likeliness studies, and ADMET prediction of quinoline imines for antimalarial activity. Chem. Sci. Trans 8(2): 208-218.

Kitchen, D.B., Decornez, H., Furr, J.R. \& Bajorath, J. 2004. Docking and scoring in virtual screening for drug discovery. Nat. Rev.: Drug Discovery 3: 935-949. 
Lipinski, C.A., Lombardo, F., Dominy, B.W. \& Feeney, P.J. 1997. Experimental and computational approaches to estimate solubility and permeability in drug discovery and development settings. Adv. Drug Delivery Rev. 23: 3-26.

O’Neill, P.M., Ward, S.A., Berry, N.G., Jeyadevan, J.P., Biagini, G.A., Asadollaly, E., Park, K.B. \& Bray P. G. 2006. A medicinal chemistry perspective on 4 -aminoquinoline antimalarial drugs. Current Topics in Medicinal Chemistry 6: 479-509.

Read, J.A., Wilkinson, K.W., Tranter, R., Sessions, R.B. \& Brady, R.L. 1999. Chloroquine binds in the cofactor binding site of plasmodium falciparum lactate dehydrogenase. The Journal of Biological Chemistry 274(15): 10213-10218.

Shadrack, D.M., Nyandoro, S., Munissi, J. \& Mubofu, E. 2016. In silico evaluation of anti-malarial agents from hoslundia opposite as inhibitors of Plasmodium falciparum lactate dehydrogenase (PfLDH) enzyme. Computational Molecular Bioscience 6: 23-32.

Thomsen, R. \& Christensen, M.H. 2006. MolDock: A new technique for high-accuracy molecular docking. Journal of Medicinal Chemistry 49(11): 3315-3321.

Trott, O. \& Olson, A. 2010. AutoDock Vina: Improving the speed and accuracy of docking with a new scoring function, efficient optimization, and multithreading. Journal of Computational Chemistry 31(2): 455-461.

Waingeh, V., Groves, A. \& Eberle, J. 2013. Binding of quinolinebased inhibitors to Plasmodium falciparum lactate dehydrogenase: A molecular docking study. Open Journal of Biophysics 2013.
WHO. 2019. World Malaria Report. Geneva: World Health Organization.

Wu, G., Robertson, D., Brooks, C. \& Vieth, M. 2003. Detailed analysis of grid-based molecular docking: A case study of CDOCKER? A CHARMm-based MD docking algorithm. Journal of Computational Chemistry 24(13): 1549-1562.

Nur Hanis Zakaria \& Nurul Izzaty Hassan*

Department of Chemical Sciences

Faculty of Science and Technology

Universiti Kebangsaan Malaysia

43600 UKM Bangi, Selangor Darul Ehsan

Malaysia

\section{Lam Kok Wai}

Drug and Herbal Research Centre

Faculty of Health Sciences

Universiti Kebangsaan Malaysia

Jalan Raja Muda Abdul Aziz

50300 Kuala Lumpur, Federal Territory

Malaysia

*Corresponding author; email: drizz@ukm.edu.my

Received: 29 January 2020

Accepted: 10 April 2020 